\title{
The Thermal Condition and Comfort Temperature of Traditional Residential Houses Located in Mountainous Tropical Areas: An Adaptive Field Study Approach
}

\author{
Hermawan $^{\#}$, Eddy Prianto ${ }^{*}$, Erni Setyowati ${ }^{*}$, Sunaryo $^{+}$ \\ \# Architecture Department, Qur'anic Science University, Kalibeber Street Wonosobo, 56351, Indonesia \\ E-mail:hermawanarsit@gmail.com \\ *Architecture Department, Diponegoro University, Semarang, 50275, Indonesia \\ E-mail: ${ }^{\# 2}$ dr.eddyprianto@gmail.com; ${ }^{\# 3}$ ernisyahdu@gmail.com \\ ${ }^{+}$Mechanical Department, Qur'anic Science University, Wonosobo, 56351, Indonesia \\ E-mail: sunaryo@fastikom-unsiq.ac.id
}

\begin{abstract}
Thermal comfort may be evaluated from the thermal condition of residential houses and their occupants' satisfaction. This research evaluates the thermal comfort of traditional residential houses located in mountainous areas of Wonosobo, Indonesia. The evaluation is conducted based on the physical condition of residential houses and their occupants' satisfaction factors. A quantitative approach is employed to analyze the theory of static thermal comfort (Predicted Mean Vote/PMV) and that of adaptive thermal comfort (Actual Mean Vote/AMV). The research method is conducted based on a field study. The thermal condition is measured using 4 climate variables and 2 personal variables. Climate variables are air temperature, globe temperature, relative humidity and wind velocity. Personal variables are clothes and activity. AMV was based on thermal sensation from ASHRAE (American Society of Heating, Refrigerating and Air-Conditioning Engineers). The sensation thermal is very cold (-3), cold (-2), cool (-1), neutral (0), warm $(+1)$, hot $(+2)$, very hot $(+3)$. The research has conducted a survey of 14 houses with 39 respondents. The research findings show that the comfort temperature is $24.47^{\circ} \mathrm{C}$ within air temperature $\left(T_{a}\right)$ or $24.14^{\circ} \mathrm{C}$ within $T_{g}$ or $24.17^{\circ} \mathrm{C}$ within $T_{0}$ or $25.08^{\circ} \mathrm{C}$ within $T_{E T}$ or $24.9^{\circ} \mathrm{C}$ within $\mathrm{T}_{\mathrm{SET}}$. These findings are compared to those previously conducted in Jakarta and Bandung showing that some differences are dealing with their comfort temperature. The other findings show that there are also some PMV and AMV differences of traditional residential houses located in the tropical mountainous areas.
\end{abstract}

Keywords-AMV; PMV; traditional residential house; thermal condition.

\section{INTRODUCTION}

The thermal comfort of residential houses is continuously observed to improve the best performance of residential houses dealing with thermal comfort. The thermal comfort of the occupants is greatly important to be investigated as basic building planning. Until now, the PMV thermal durability theory has still been investigated to obtain a perfect theory [1]. In the theory of thermal comfort, the physical condition of the building needs to be examined together with the conditions of the occupants of the building. In Research in Bangladesh, thermal comfort is only seen from the physical side of the building. The results showed that roof conditions influence the thermal comfort in a room. The study revealed that the heat transmission generated is influenced by vegetation on the roof of buildings. This research does not examine the occupants' condition nor provide air temperature conditions used to create the occupants' thermal comfort [2].

Several studies of thermal comfort involving occupants have been carried out. Most research is done in offices. There is still little research on thermal comfort in homes. Thermal comfort studies in offices have been carried out on mixed ventilated and artificially ventilated office buildings. The results of the study showed a temperature difference between men and women [3]. Thermal comfort research to determine the comfortable temperature is essential, so that, the indoor planning in the architecture can be adjusted to the comfortable temperature conditions of the occupants. Energy savings can be done if the room temperature is in accordance with the comfortable temperature of the occupants because there is no need for cooling or heating devices. The temperature of the outer space influences the indoor 
temperature, but the indoor temperature in determining the thermal comfort of the occupants of the room. The outdoor temperature has been believed to be closely related to the temperature of the inner chamber, but the relationship between the temperature of the indoor and thermal comfort is not widely known. Indoor temperature is vital to know the relationship with the thermal comfort of the occupants to determine the comfortable temperature of the occupants.

An analysis of architectural comfort may be conducted in several ways. Thermal comfort research frequently results in a mathematical equation and analysis using graphs [4]-[6]. The use of mathematical equations to produce comfortable temperatures has been carried out in the study of adaptive thermal comfort in Qatar. The study explains the relationship between outdoor temperature, internal temperature and thermal sensation as a basis for thermal comfort. The results obtained are the comfortable temperature of the occupants [7].

The neutral temperature equation in each room has different results that, when determining the architectural design, disparate treatment is required in each room. The thermal comfort felt by building users in each room is different as is the case in Brazil which quantitatively and qualitatively aims at improving the thermal performance [8]. The research is conducted using a field study by comparing the energy efficiency strategy with the simulation. The finding shows that the thermal comfort model revealing the indoor thermal comfort and energy conservation within the buildings under investigation is an imbalance.

Maiti has experimented in the laboratory by measuring the thermal variables and physical parameters, such as skin $\left(\mathrm{T}_{\mathrm{sk}}\right)$, oral temperature $\left(\mathrm{T}_{\mathrm{c}}\right)$, and subjective respond of thermal sensation (TSV) [9]. $\mathrm{T}_{\mathrm{b}}$ (body temperature) is obtained from Tsk and Tc. PMV tries to accommodate the adaptive thermal comfort using Tsk equation. However, the result shows that PMV is not adequately good to provide the adaptive thermal comfort in India.

Adaptive thermal comfort is influenced by physiological factors such as age, sex, and body mass index [10]. Based on this, personal factors are important variables in adaptive thermal comfort. Personal factors consist of clothing and activity variables. Therefore, the prediction of the comfortable temperature of building occupants is an important finding in the thermal comfort of buildings.

The other study is also conducted to investigate the occupants' response to the thermal comfort in hot and cold weather. That study explores the strategies in dealing with the heat and cold. It is found that the strategies used are turning on the fan, opening or closing the doors or windows, and adjusting the clothes and activities [11].

Besides in residential buildings, the study is also conducted at schools-at laboratories, classrooms, and administrative rooms. This field study is conducted to measure the climate variables, including air temperature and humidity which are calculated with the PMV theory. The finding shows that the thermal condition environment does not satisfy the occupants. High temperature is found in the laboratories due to the heat-generating computers [12].

The results of some previous studies show that the buildings both at schools and residential houses have different thermal comforts. The research method on adaptive thermal comfort may also be conducted either through simulation, experiment or field study. Those three components may result in researches with adaptive thermal comforts used as a reference for architectural designing.

In the field of architecture, the traditional residential houses are presumably able to realize the occupants' thermal comfort revealing the building thermal comfort in conventional buildings is greatly required. It is necessary to research traditional residential houses since many Indonesian people, especially those coming from the lower and middle social-economic class, live in those houses. They are spread in various areas, particularly in mountainous areas. There are several types of traditional residential houses in mountainous areas based on their wall materials, including wooden and river stone wall houses. Different wall materials may lead to the various indoor temperature that eventually influences the occupants' thermal comfort (see table 1).

TABLE I

HOUSE PROFILE

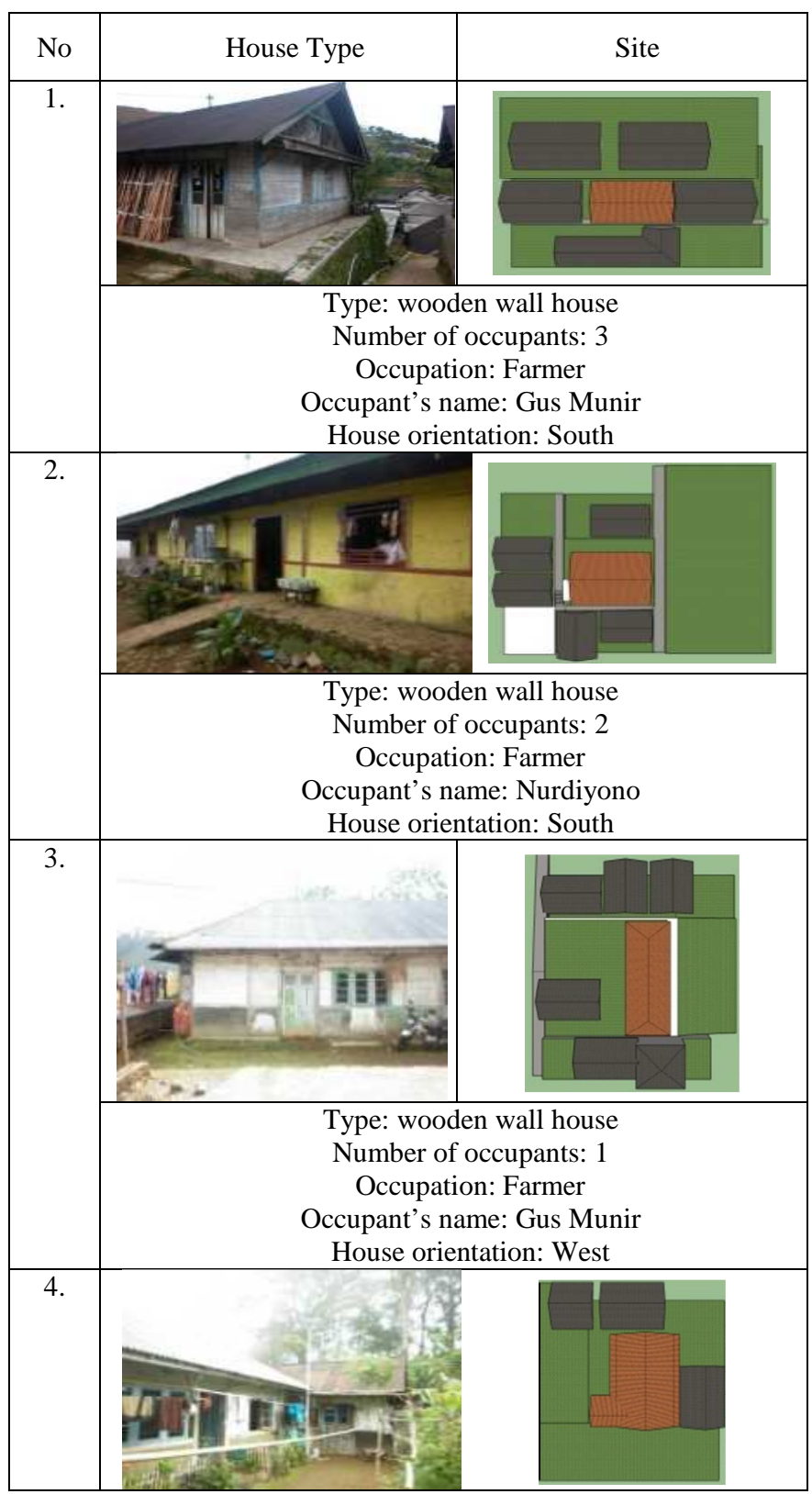




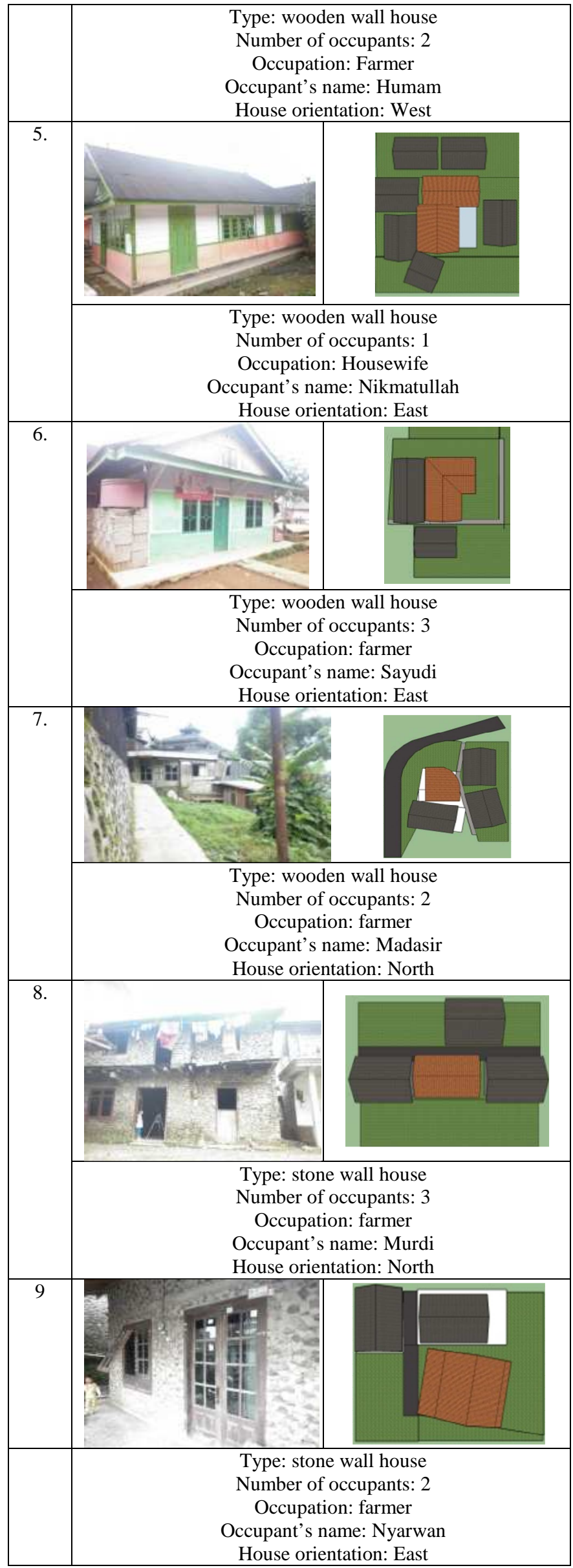

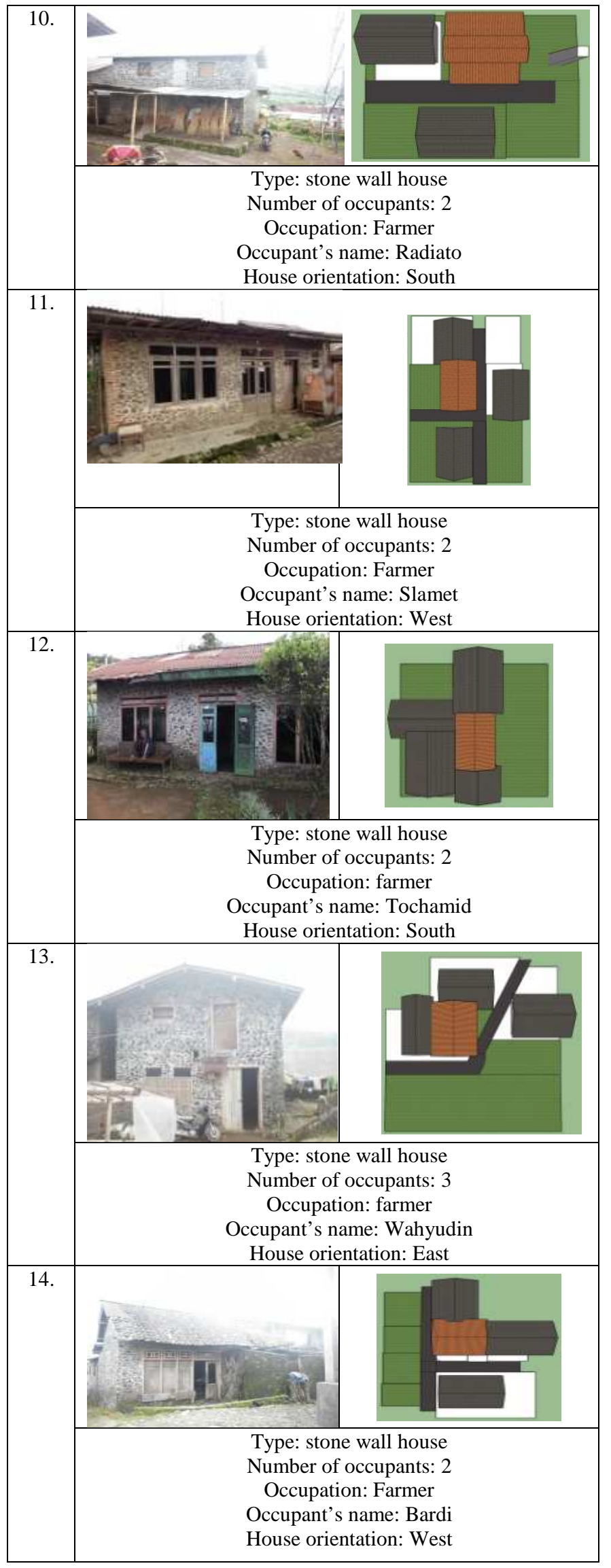

The scope of this research is related to the study of adaptive thermal comfort with the finding of thermal comfort of traditional residential houses in the low (cold) 
temperature mountainous areas. The objectives of this research are as follows:

- Analyze the thermal condition of traditional residential houses located in the tropical areas

- Examine the influence of thermal variables on thermal perception obtained from AMV (Actual Mean Vote).

- Analyze the implementation differences between the Auliciems' and Humphreys' Neutral Temperature of traditional residential houses located in the mountainous tropical areas.

The significance of this research is as a room's temperature comfort standard to design the architectural building in the cold area due to the finding on the comfort temperature of the traditional residential houses located in the mountainous regions.

\section{MATERIALS AND METHOD}

This research is conducted on the wooden and river stone walled traditional residential houses. The researchers have conducted a survey on 14 houses with 39 respondents that 115 datasets or 2645 data are obtained. The data are analyzed based on climate and personal variables including temperature $\left(\mathrm{T}_{\mathrm{a}}\right)$, globe temperature $\left(\mathrm{T}_{\mathrm{g}}\right)$, air humidity $(\mathrm{RH})$, wind velocity (v), clothing (clo), and activity (met). The measuring devices used are globe thermometer $\left(\mathrm{T}_{\mathrm{g}}\right)$ with a diameter of $15 \mathrm{~cm}$, digital hygrothermometer functioning to measure the air temperature and humidity, and digital anemometer performing to measure the wind velocity. Besides, climate variables, personal data are also required, such as age, sex, height, and weight. Those measuring devices are placed in the living room starting from 8 a.m. to 5.00 p.m. set at $1.2 \mathrm{~m}$ to measure the standing occupants and at $0.6 \mathrm{~m}$ for the sitting occupants. During the data collection, the occupants move closer to $0.5 \mathrm{~m}$ to $1 \mathrm{~m}$ away from those measuring devices.

The data are then calculated to obtain the results of PMV, PPD, $\mathrm{T}_{\mathrm{SENS}}$, DISC, $\mathrm{T}_{\mathrm{ET}}, \mathrm{T}_{\mathrm{SET}}$, Tneutral Humphreys and Tneutral Auliciems, as well as $\mathrm{T}_{\mathrm{o}}$. The respondents' thermal sensation data are used to examine the influence of thermal sensation on the existing thermal variables. This has been conducted by another research in his field of study to examine the neutral temperature and comfort temperature of campus buildings. The regression equation of AMV (Actual Mean Vote) with the climate variables (air temperature and operative temperature) was described [13]. The data are collected three times a day at the same time with the measured climate variables based on the following seven scale points: very cold $(-3)$, cold $(-2)$, cool $(-1)$, neutral $(0)$, warm $(+1)$, hot $(+2)$, very hot $(+3)$ [14]. The height of the measuring devices is shown in fig 1 .

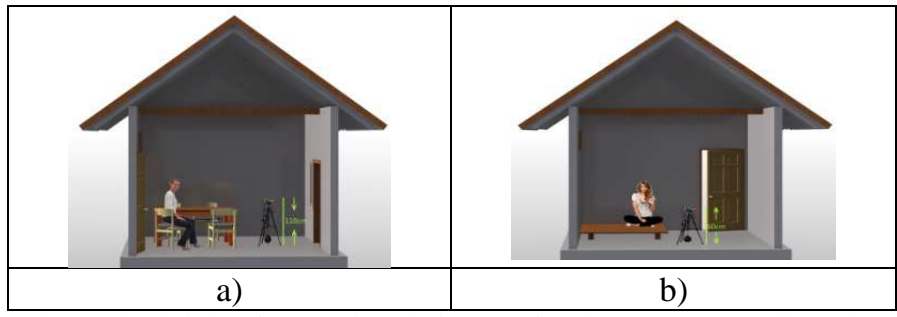

Fig 1. The height of measuring devices: a) for the occupants to sit on the chair b) for the occupants to sit on the floor

\section{RESULT S AND DISCUSSION}

The data based on thermal variables are measured every 60 minutes at each house's living room which may be seen in figure 2 and 3.

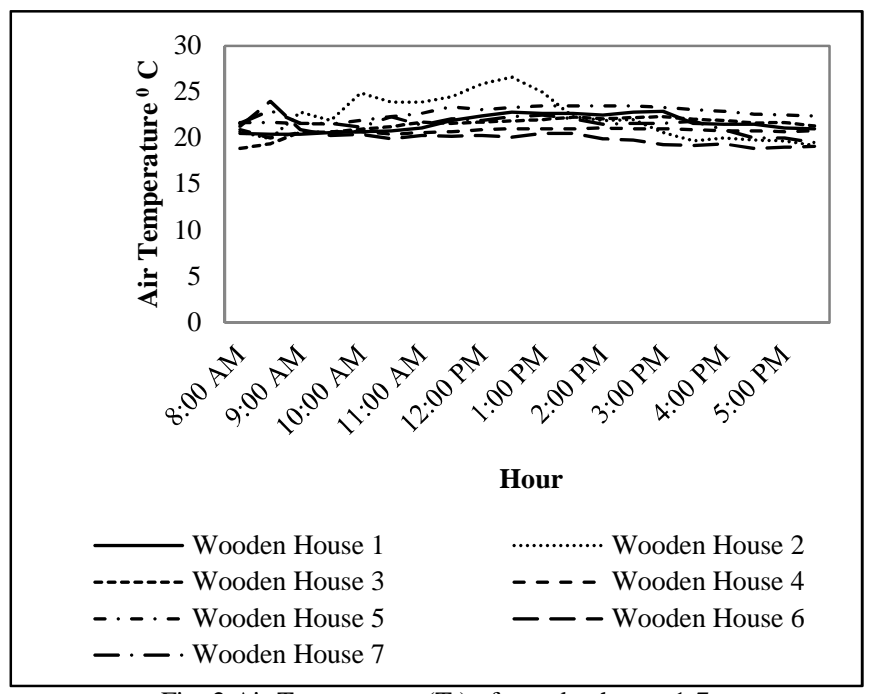

Fig. 2 Air Temperature $\left(\mathrm{T}_{\mathrm{a}}\right)$ of wooden house 1-7

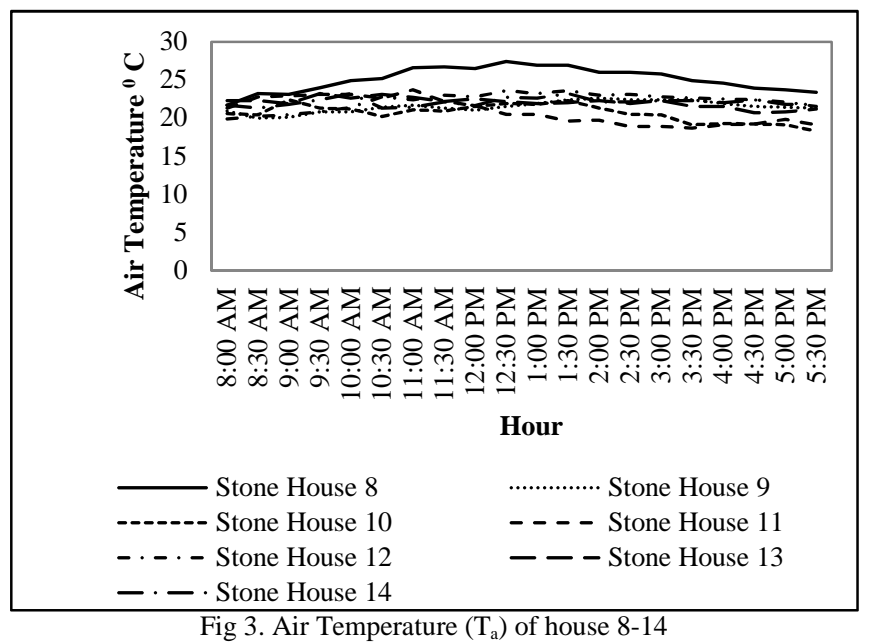

The air temperature of the sample houses shows no significant difference. The highest temperature is from house 2 of the sample house $1-7$ with $26.2^{\circ} \mathrm{C}$. For the sample house $8-14$, the highest temperature is from house 8 with $27.4^{\circ} \mathrm{C}$. House 2 is facing the south and since it is on sunny day, sunshine is unable to penetrate the house and without any obstruction from the neighboring houses. House 8 is facing to the north and similar conditions take place. House 2 is a wooden wall house while house 8 is a stone wall house. Thus, the highest temperature is exposed by the stone walled residential houses. Of the sample house 1-7, the lowest temperature is from house 3 with $18.8^{\circ} \mathrm{C}$. Meanwhile, of the sample house 8-14, the lowest temperature is from house 10 with $18.3^{\circ} \mathrm{C}$. The stone wall houses expose the maximum and minimum temperatures. Meanwhile, the river stone wall houses may create both maximum and minimum air temperature. The average maximum and minimum temperatures are shown in Table 2.

The average air temperature of the wooden wall houses is between $20.2^{\circ} \mathrm{C}-22.7^{\circ} \mathrm{C}$, while those of the exposed stone 
wall houses are between $21.5^{\circ} \mathrm{C}-25.1^{\circ} \mathrm{C}$. It shows that there is a significant difference in the average temperature of the exposed stone wall houses. It means that in storing heat, wooden materials are more stable than the stone. Both materials have been utilized for centuries through many trials and errors. The utilization depends on those materials' availability.

TABLE II

THE AIR TEMPERATURE PROFILE

\begin{tabular}{|c|c|c|c|c|c|}
\hline $\begin{array}{c}\text { Sample } \\
\text { house }\end{array}$ & $\begin{array}{c}\text { Minimum } \\
\mathrm{T}_{\mathrm{a}}\end{array}$ & Hour & $\begin{array}{c}\text { Maximum } \\
\mathrm{T}_{\mathrm{a}}\end{array}$ & Hour & $\begin{array}{c}\mathrm{T}_{\mathrm{a}} \\
\text { mean }\end{array}$ \\
\hline 1 & $20.4^{\circ} \mathrm{C}$ & $9 \mathrm{am}$ & $22.9^{\circ} \mathrm{C}$ & $3 \mathrm{pm}$ & $21.6^{\circ} \mathrm{C}$ \\
\hline 2 & $19.2^{\circ} \mathrm{C}$ & $5.30 \mathrm{pm}$ & $26.6^{\circ} \mathrm{C}$ & $\begin{array}{c}12.30 \\
\mathrm{pm}\end{array}$ & $22.3^{\circ} \mathrm{C}$ \\
\hline 3 & $18.8^{\circ} \mathrm{C}$ & $8 \mathrm{am}$ & $22.31^{\circ} \mathrm{C}$ & $3 \mathrm{pm}$ & $21.4^{\circ} \mathrm{C}$ \\
\hline 4 & $20^{\circ} \mathrm{C}$ & $8.30 \mathrm{am}$ & $21.1^{\circ} \mathrm{C}$ & $2 \mathrm{pm}$ & $20.8^{\circ} \mathrm{C}$ \\
\hline 5 & $21.5^{\circ} \mathrm{C}$ & $9.30 \mathrm{am}$ & $23.5^{\circ} \mathrm{C}$ & $2.30 \mathrm{pm}$ & $22.7^{\circ} \mathrm{C}$ \\
\hline 6 & $18.9^{\circ} \mathrm{C}$ & $4.30 \mathrm{pm}$ & $24^{\circ} \mathrm{C}$ & $8.30 \mathrm{am}$ & $20.2^{\circ} \mathrm{C}$ \\
\hline 7 & $19.5^{\circ} \mathrm{C}$ & $5.30 \mathrm{pm}$ & $23^{\circ} \mathrm{C}$ & $8.30 \mathrm{am}$ & $21.5^{\circ} \mathrm{C}$ \\
\hline 8 & $21.7^{\circ} \mathrm{C}$ & $8 \mathrm{am}$ & $27.4^{\circ} \mathrm{C}$ & $\begin{array}{c}12.30 \\
\mathrm{pm}\end{array}$ & $25.1^{\circ} \mathrm{C}$ \\
\hline 9 & $20^{\circ} \mathrm{C}$ & $8.30 \mathrm{am}$ & $22.6^{\circ} \mathrm{C}$ & $2 \mathrm{pm}$ & $21.5^{\circ} \mathrm{C}$ \\
\hline 10 & $18.3^{\circ} \mathrm{C}$ & $5.30 \mathrm{pm}$ & $22.4^{\circ} \mathrm{C}$ & $9 \mathrm{am}$ & $20.6^{\circ} \mathrm{C}$ \\
\hline 11 & $18.7^{\circ} \mathrm{C}$ & $3.30 \mathrm{pm}$ & $23.7^{\circ} \mathrm{C}$ & $11 \mathrm{am}$ & $20.9^{\circ} \mathrm{C}$ \\
\hline 12 & $19.9^{\circ} \mathrm{C}$ & $8 \mathrm{am}$ & $23.6^{\circ} \mathrm{C}$ & $\begin{array}{c}12.30 \\
\mathrm{pm}\end{array}$ & $22.2^{\circ} \mathrm{C}$ \\
\hline 13 & $20.7^{\circ} \mathrm{C}$ & $4.30 \mathrm{pm}$ & $23.2^{\circ} \mathrm{C}$ & $9.30 \mathrm{am}$ & $22.1^{\circ} \mathrm{C}$ \\
\hline $21.3^{\circ} \mathrm{C}$ & $8.30 \mathrm{am}$ & $23.2^{\circ} \mathrm{C}$ & $10 \mathrm{am}$ & $22.1^{\circ} \mathrm{C}$ \\
\hline 14 & & & & &
\end{tabular}

The other thermal variable to investigate is humidity. There is no significant difference in the minimum humidity which is only by $74.9^{\circ} \mathrm{C}-88.9^{\circ} \mathrm{C}$ in the sample house $1-7$ (wooden wall houses). Conversely, the significant difference is shown in sample houses 8-14 (exposed stone wall houses), which is by $50.6^{\circ} \mathrm{C}-85.2^{\circ} \mathrm{C}$. The maximum humidity difference of wooden wall houses is ranging from $83.8^{\circ} \mathrm{C}-$ $91.2^{\circ} \mathrm{C}$ (See Fig. 4 and 5), while that of the exposed stone wall houses is ranging from $82.8^{\circ} \mathrm{C}-93.4^{\circ} \mathrm{C}$.

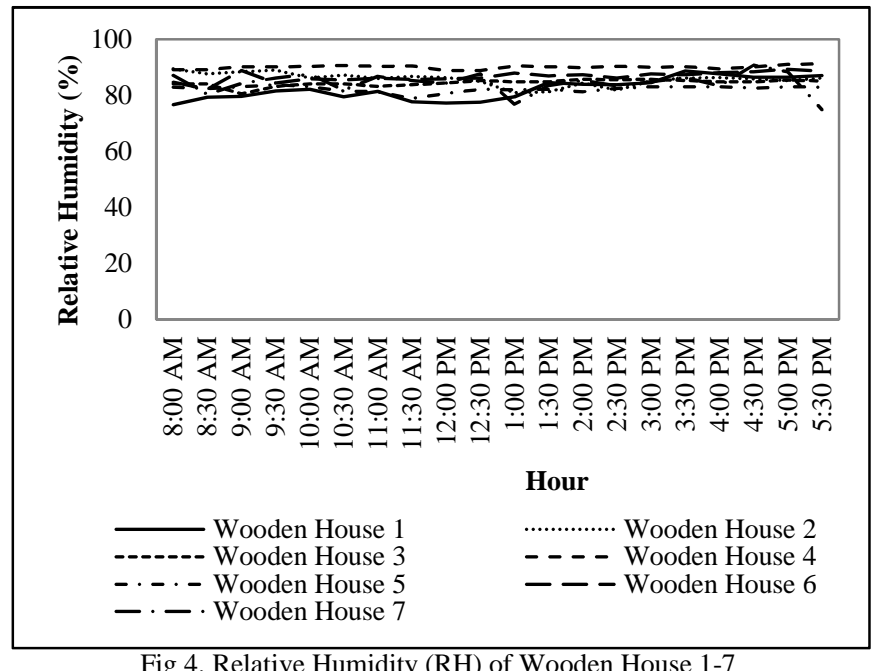

Fig 4. Relative Humidity (RH) of Wooden House 1-7

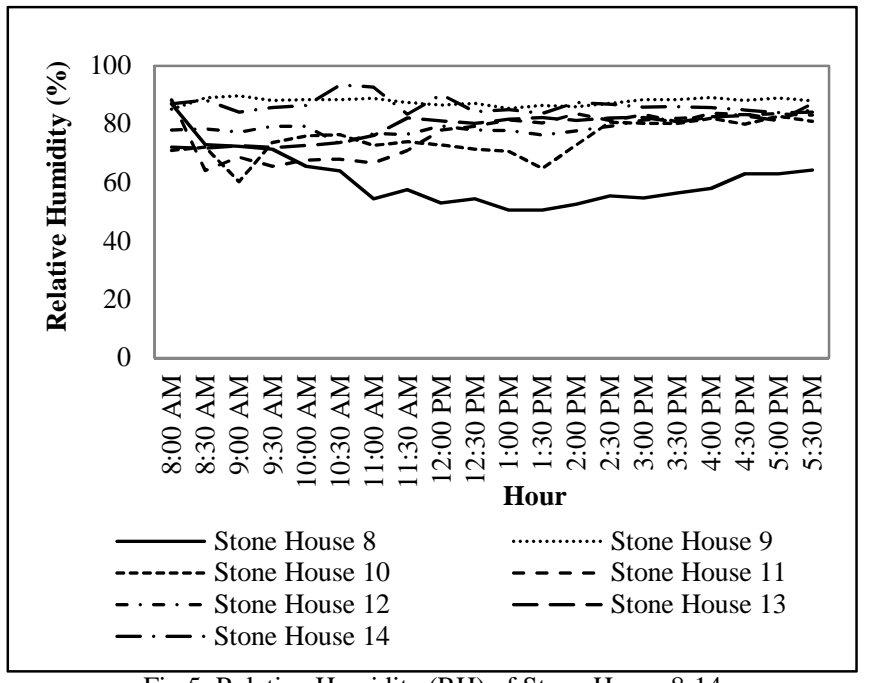

Fig 5. Relative Humidity (RH) of Stone House 8-14

The lowest minimum humidity takes place in house 7 lying on the steep slope and facing to the north. The highest minimum humidity takes place in house 4 facing to west and bordered by the neighboring houses. Table 3 provides a clearer view on the humidity data.

TABLE III

RELATIVE HUMIDITY PROFILE

\begin{tabular}{|c|c|c|c|c|c|}
\hline $\begin{array}{c}\text { Sample } \\
\text { house }\end{array}$ & $\begin{array}{c}\text { Minimum } \\
\text { RH }\end{array}$ & Hour & $\begin{array}{c}\text { Maximum } \\
\text { RH }\end{array}$ & Hour & $\begin{array}{c}\text { RH } \\
\text { mean }\end{array}$ \\
\hline 1 & $76.70 \%$ & $8 \mathrm{am}$ & $88.70 \%$ & $3.30 \mathrm{pm}$ & $82.26 \%$ \\
\hline 2 & $80.90 \%$ & $1 \mathrm{pm}$ & $89.40 \%$ & $8 \mathrm{am}$ & $85.74 \%$ \\
\hline 3 & $80.57 \%$ & $9 \mathrm{am}$ & $85.76 \%$ & $3 \mathrm{pm}$ & $84.44 \%$ \\
\hline 4 & $88.90 \%$ & $12.30 \mathrm{pm}$ & $91.20 \%$ & $5.30 \mathrm{pm}$ & $90.04 \%$ \\
\hline 5 & $78.90 \%$ & $11.30 \mathrm{am}$ & $83.80 \%$ & $9.30 \mathrm{am}$ & $82.26 \%$ \\
\hline 6 & $82.20 \%$ & $8.30 \mathrm{am}$ & $89.30 \%$ & $5 \mathrm{pm}$ & $86.63 \%$ \\
\hline 7 & $74.90 \%$ & $5.30 \mathrm{pm}$ & $90.70 \%$ & $4.30 \mathrm{pm}$ & $84.40 \%$ \\
\hline 8 & $50.60 \%$ & $1.30 \mathrm{pm}$ & $87 \%$ & $8 \mathrm{am}$ & $61.13 \%$ \\
\hline 9 & $85.20 \%$ & $8 \mathrm{am}$ & $89.80 \%$ & $9 \mathrm{am}$ & $87.80 \%$ \\
\hline 10 & $60.40 \%$ & $9 \mathrm{am}$ & $82.80 \%$ & $5 \mathrm{pm}$ & $74.85 \%$ \\
\hline 11 & $64.20 \%$ & $8.30 \mathrm{am}$ & $88.30 \%$ & $8 \mathrm{am}$ & $77.17 \%$ \\
\hline 12 & $73.40 \%$ & $10.30 \mathrm{am}$ & $85.20 \%$ & $5.30 \mathrm{pm}$ & $79.24 \%$ \\
\hline 13 & $71.80 \%$ & $8.30 \mathrm{am}$ & $87 \%$ & $5.30 \mathrm{pm}$ & $76.38 \%$ \\
\hline 14 & $83.80 \%$ & $1.30 \mathrm{pm}$ & $93.40 \%$ & $10.30 \mathrm{am}$ & $82.2 \%$ \\
\hline
\end{tabular}

From the above-mentioned data, it shows that the lowest Ta (air temperature) is from house 10 with $18.3^{\circ} \mathrm{C}$, and the highest is from house 8 with $27.4^{\circ} \mathrm{C}$. The lowest MRT (average sun radiation) is from house 11 with $17.1^{\circ} \mathrm{C}$ and the highest is from house 8 with $27.9^{\circ} \mathrm{C}$. The lowest Ta and MRT take place in the afternoon around $4.30 \mathrm{p} . \mathrm{m}$. and the highest also occur in the afternoon around 11.30-12.30 p.m. Meanwhile, the lowest RH (relative humidity) is from house 8 with $50.6 \%$ at 1.30 p.m. and the highest is from house 14 with $93.4 \%$ at around 10.30 a.m. The lowest V (wind movement) is from most of the houses with $0 \mathrm{~m} / \mathrm{s}$ for a long period, while the highest is from house 14 with $0.11 \mathrm{~m} / \mathrm{s}$ at 5.30 p.m. Those may be seen in Table 4. 
TABLE IV

RECAPITULATION OF THERMAL VARIABLES

\begin{tabular}{|c|c|c|c|c|c|c|}
\hline Variable & Hour & Min & House & Hour & Max & House \\
\hline Ta & $\begin{array}{c}5.30 \\
\text { p.m. }\end{array}$ & $18.3^{\circ} \mathrm{C}$ & $\begin{array}{c}\text { House } \\
10\end{array}$ & $\begin{array}{c}12: 30 \\
\text { p.m. }\end{array}$ & $27.4^{\circ} \mathrm{C}$ & $\begin{array}{c}\text { House } \\
8\end{array}$ \\
\hline RH & $\begin{array}{c}1.30 \\
\text { p.m. }\end{array}$ & $50.6 \%$ & $\begin{array}{c}\text { House } \\
8\end{array}$ & $\begin{array}{c}10: 30 \\
\text { a.m. }\end{array}$ & $93.4 \%$ & $\begin{array}{c}\text { House } \\
14\end{array}$ \\
\hline MRT & $\begin{array}{c}4 \\
\text { p.m. }\end{array}$ & $17.1^{\circ} \mathrm{C}$ & $\begin{array}{c}\text { House } \\
11\end{array}$ & $\begin{array}{c}11: 30 \\
\text { a.m. }\end{array}$ & $27.9^{\circ} \mathrm{C}$ & $\begin{array}{c}\text { House } \\
8\end{array}$ \\
\hline $\mathrm{V}$ & - & $0.00 \mathrm{~m} / \mathrm{s}$ & - & $\begin{array}{c}5: 30 \\
\text { p.m. }\end{array}$ & $0.11 \mathrm{~m} / \mathrm{s}$ & $\begin{array}{c}\text { House } \\
14\end{array}$ \\
\hline
\end{tabular}

The age of occupants who become the respondents of this research varies from 10 to 80 years. The survey shows that there are more male respondents than the female ones $(71 \%$ males and $39 \%$ females). Their height is minimally $110 \mathrm{~cm}$ and maximally $175 \mathrm{~cm}$ that the average height is $160.65 \mathrm{~cm}$. The Respondents' weight is minimally $32 \mathrm{~kg}$ and maximally is $80 \mathrm{~kg}$ that their average weight is $55.80 \mathrm{~kg}$. The respondents' body weight and height are used as the data to calculate the $\mathrm{Du}$ Bois Area $\left(\mathrm{A}_{\mathrm{DU}}\right)$ to figure out the whole skin extent.

Du Bois Area $\left(A_{D U}\right)$ is a human body's surface area calculated by using the equation which combines the body weight and height. The calculation is conducted based on the McIntyre equation, which is $A_{D U}=0.202 \mathrm{~W}^{0.25} \mathrm{H}^{0.725}$. The obtained minimum $A_{D U}$ is $26.61 \mathrm{~cm}^{2}$, the maximum is 55.00 $\mathrm{cm}^{2}$, and the mean is $44.23 \mathrm{~cm}^{2}$.

The finding has proven what has been found by Khalid, who discusses the occupants' discomfort based on the existing standards. Thermal comfort temperature is ranging between $25.3^{\circ} \mathrm{C}$ and $25.5^{\circ} \mathrm{C}$ in Malaysia. The measurements conducted on hospital buildings in Malaysia show that between the indoor comfort temperature and running mean outdoor temperature is ranging from $27^{\circ} \mathrm{C}-31^{\circ} \mathrm{C}$ [15]. Thus, the thermal discomfort in those buildings is undeniable. The researchers also include the design and non-thermal factors that may influence the occupants' adaptive behaviors and their thermal satisfaction, such as operation control and maintenance, mosquitoes, and noise as well as the occupants' behaviors, age, and status. Those factors influence their subjective responses of thermal sensation vote (TSV). The research emphasizes that those may be controlled by the occupants such as windows, comforting building element addition like plant boxes in front of the windows, and the mosquito screen. These should be incorporated when designing a building to improve the occupants' thermal comfort.

The window is one factor that enables the air to flow through the buildings. Thus, it is essential for those in hot areas. Due to its great importance, it is necessary to adjust the window design with its area. Customizing the design is also important to the rooms which do not require bigger airflow. Research on the relationship between windows and airflow has been carried out by several researchers using simulation methods. The results of the study mentioned that the type of window affects the airflow. The determination of the window needs to be adjusted to the climate variable at a place [16], [17].
Prianto, Bonneaud, Depecker \& Peneau also find that balcony and void configuration significantly influence the maximum comfort speed. They also find the prominence of traditional houses dealing with the climate [18][19].

The air temperature in all residential houses understudy is between $19.3^{\circ} \mathrm{C}$ and $32.7^{\circ} \mathrm{C}$ with an average of $24.24^{\circ} \mathrm{C}$. The globe temperature is between $17.1^{\circ} \mathrm{C}$ and $31.7^{\circ} \mathrm{C}$ with an average of $23.61^{\circ} \mathrm{C}$. $\mathrm{T}_{\mathrm{o}}$ is obtained from the air temperature date $\left(\mathrm{T}_{\mathrm{a}}\right)$ and globe temperature $\left(\mathrm{T}_{\mathrm{g}}\right)$. The result is between $18.6^{\circ} \mathrm{C}$ and $32.2^{\circ} \mathrm{C}$ with an average of $23.93^{\circ} \mathrm{C}$. Wind speed is between $0 \mathrm{~m} / \mathrm{s}$ and $0.3 \mathrm{~m} / \mathrm{s}$. In PMV (Predicted Mean Vote) calculation, the wind speed is between $0 \mathrm{~m} / \mathrm{s}-0.1 \mathrm{~m} / \mathrm{s}$ and calculated as $0.1 \mathrm{~m} / \mathrm{s}$. The average wind speed is $0.11 \mathrm{~m} / \mathrm{s}$. Air humidity is between $63 \%$ and $96 \%$. The humidity average is $80.74 \%$. The sitting and talking activities require 1.2 met.

Some results are obtained using the ASHRAE Basic Thermal Comfort Model. PMV value is between -2.36 (between cold and very cold) and 2.45 (between warm and hot). Its average is 0.057 (between neutral and slightly warm). The value of PPD (Predicted Percentage Dissatisfied) is between $5 \%$ and $92 \%$. The value of $\mathrm{T}_{\mathrm{ET}}$ (Equivalent Temperature) is between $18.9^{\circ} \mathrm{C}$ and $34^{\circ} \mathrm{C}$ with an average of $24.7^{\circ} \mathrm{C}$. The value of $\mathrm{T}_{\mathrm{SET}}$ (Standard Effective Temperature) is between $10^{\circ} \mathrm{C}$ and $33.6^{\circ} \mathrm{C}$. The linear regression of AMV (Actual Mean Vote) with the temperatures $\left(\mathrm{T}_{\mathrm{a}}, \mathrm{T}_{\mathrm{g}}, \mathrm{T}_{\mathrm{o}}\right.$, and $\left.\mathrm{T}_{\mathrm{SET}}\right)$ may be conducted to determine $\mathrm{Tn}$ and the comfort zone. Tn is obtained when AMV equals to 0 , while $\mathrm{T}_{\mathrm{cr}}$ (comfort temperature) is obtained when AMV equals to -0.5 and +0.5 .

Based on the statistical testing results, some equations are formulated as follows:

- The influence of users' perception (AMV) on temperature $\left(\mathrm{T}_{\mathrm{a}}\right)$ : $\mathrm{AMV}=0.190 \mathrm{~T}_{\mathrm{a}}-4.651$. With this equation, $\mathrm{T}_{\mathrm{n}}$ which is equal to $24.47^{\circ} \mathrm{C} \mathrm{T}_{\mathrm{a}}$ may be determined when $\mathrm{T}_{\text {cr }}$ is ranging from $21.85^{\circ} \mathrm{C}-$ $27.11^{\circ} \mathrm{C} \mathrm{T}_{\mathrm{a}}$.

- The influence of users' perception (AMV) on $\left(\mathrm{T}_{\mathrm{g}}\right)$ : AMV $=0.199 \mathrm{~T}_{\mathrm{g}}-4.805$. With this equation, $\mathrm{T}_{\mathrm{n}}$, which is equal to $24.14^{\circ} \mathrm{C} \mathrm{T}_{\mathrm{g}}$ may be determined when $\mathrm{T}_{\mathrm{cr}}$ is ranging from $21.63^{\circ} \mathrm{C}-26.65^{\circ} \mathrm{C} \mathrm{T}_{\mathrm{g}}$.

- The influence of users' perception (AMV) on $\left(\mathrm{T}_{\mathrm{o}}\right)$ : AMV $=0.199 \mathrm{~T}_{\mathrm{o}}-4.810$. With this equation, $\mathrm{T}_{\mathrm{n}}$ is equal to $24.17^{\circ} \mathrm{C}$ to may be determined when $\mathrm{T}_{\mathrm{cr}}$ is ranging from $21.65^{\circ} \mathrm{C}-26.68^{\circ} \mathrm{C} \mathrm{T}_{\mathrm{o}}$.

- The influence of users' perception $(A M V)$ on $\left(\mathrm{T}_{\mathrm{ET}}\right)$ : $\mathrm{AMV}=0.175 \mathrm{~T}_{\mathrm{ET}}-4.389$. With this equation, $\mathrm{T}_{\mathrm{n}}$, which is equal to $25.08^{\circ} \mathrm{C} \mathrm{T}_{\mathrm{ET}}$ may be determined when $\mathrm{T}_{\mathrm{cr}}$ is ranging from $22.22^{\circ} \mathrm{C}-27.93^{\circ} \mathrm{C} \mathrm{T}_{\mathrm{ET}}$.

- The influence of users' perception (AMV) on $\left(\mathrm{T}_{\mathrm{SET}}\right)$ : $\mathrm{AMV}=0.191 \mathrm{~T}_{\mathrm{SET}}-4.716$. With this equation, $\mathrm{T}_{\mathrm{n}}$ which is equal to $24.69^{\circ} \mathrm{C}$ TSET may be determined when $\mathrm{T}_{\mathrm{cr}}$ is ranging from $22.07^{\circ} \mathrm{C}-27.30^{\circ} \mathrm{C} \mathrm{T}_{\mathrm{SET}}$.

The regression equation graphs are shown at fig 6-10 as follows: 


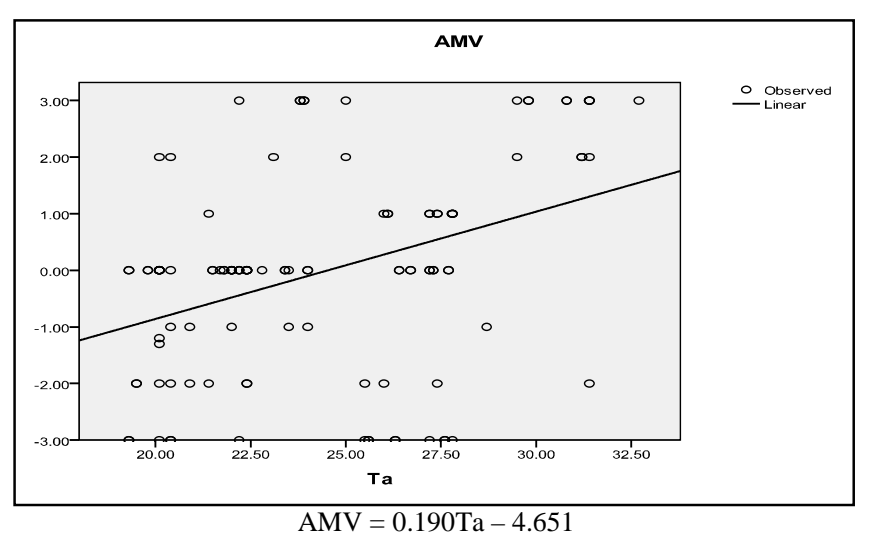

Fig 6. The regression of AMV on $T_{a}$

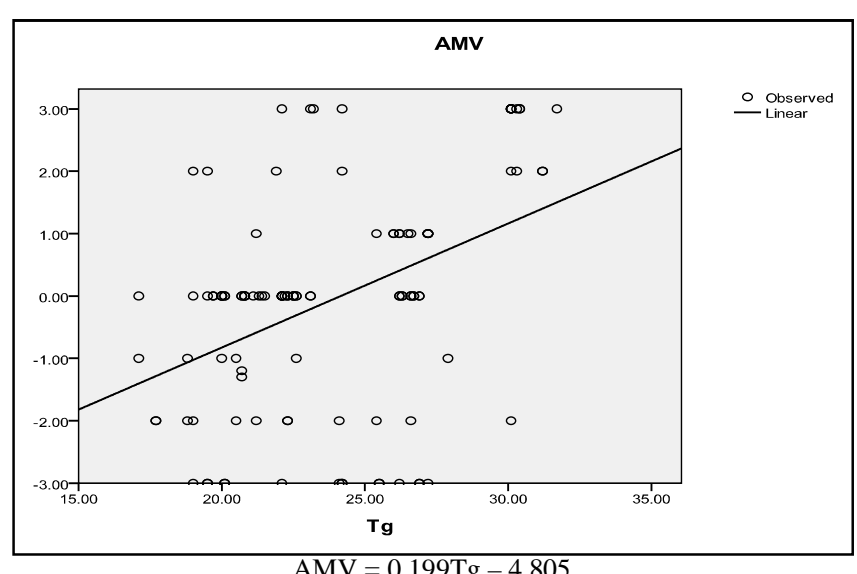

$\mathrm{AMV}=0.199 \mathrm{Tg}-4.805$.

Fig 7. The regression of AMV on $T_{g}$

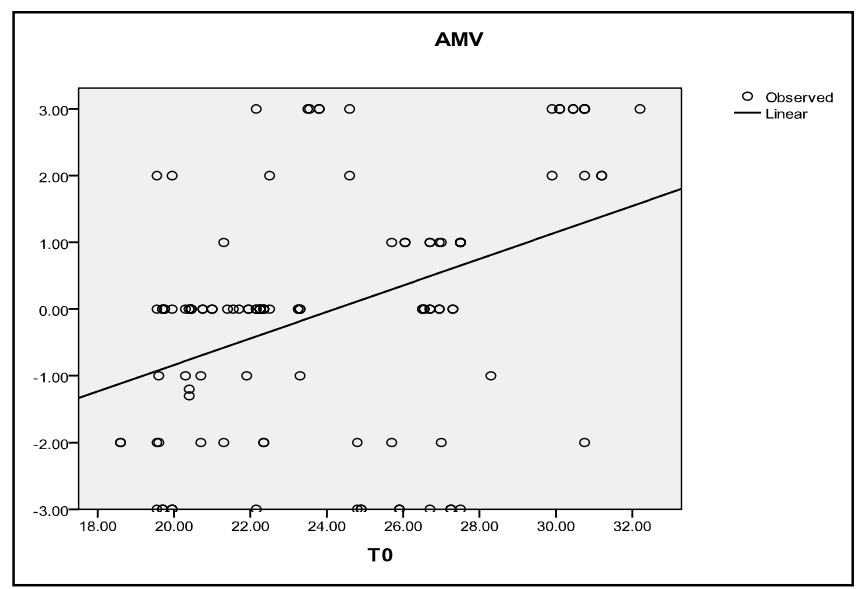

$\mathrm{AMV}=0.199 \mathrm{To}-4.810$

Fig 8. The regression of AMV on $T_{0}$

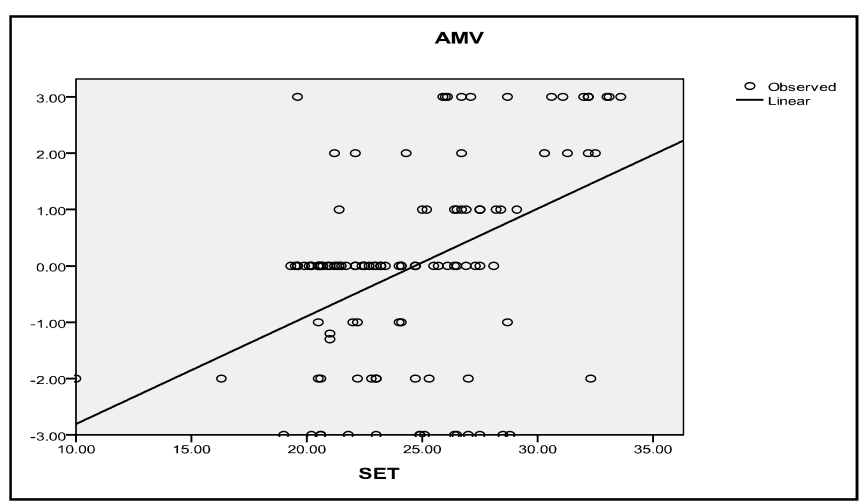

AMV $=0.175$ TET -4.389

Fig 9. The regression of AMV on $\mathrm{T}_{\mathrm{ET}}$

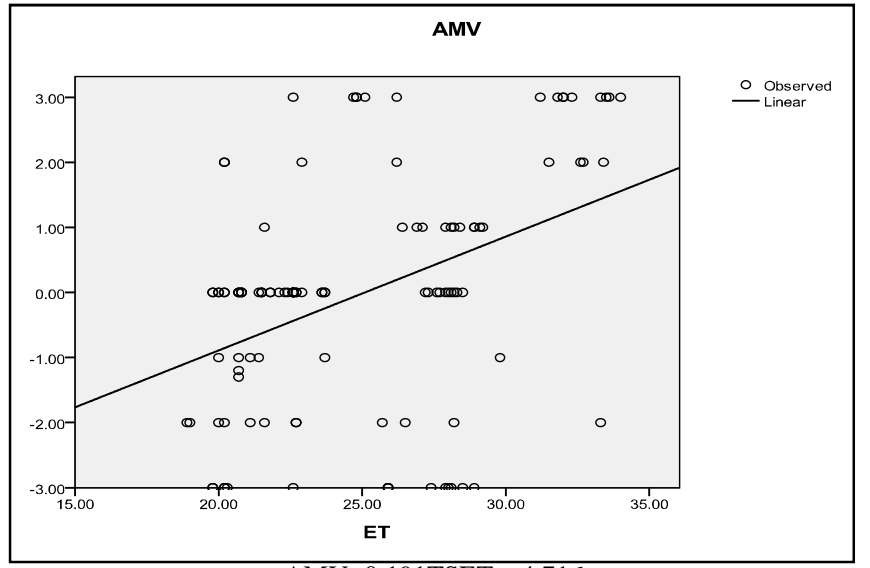

AMV $=0.191 \mathrm{TSET}-4.716$

Fig 10. The regression of AMV on $\mathrm{T}_{\mathrm{SET}}$

The comparative study on thermal comfort conducted in Jakarta and Bandung is shown in table 5. There are some differences in the calculation results of the office buildings in Jakarta and the college buildings in Bandung [20]. The smallest difference is found from the study conducted on the college buildings at the neutral temperature using air temperature between $24.7^{\circ} \mathrm{C}$ and $24.47^{\circ} \mathrm{C}$ with a deviation of only $0.23^{\circ} \mathrm{C}$. The most significant difference between $27.2^{\circ} \mathrm{C}$ and $24.17^{\circ} \mathrm{C}$ is found in the neutral temperature using the operative temperature at the office buildings in Jakarta with the distinction of the only $3.03^{\circ} \mathrm{C}$. This research has a reasonable consideration as it is conducted in mountainous areas with lower average temperatures than those conducted in Jakarta and Bandung.

The comfort temperature regarding the equivalent temperature shows a slight difference of only by $0.52^{\circ} \mathrm{C}$, between the office buildings in Jakarta and the residential houses in Wonosobo. The equal comfort temperature of those office buildings is higher than that of residential houses. Meanwhile, the college buildings in Bandung show that their SET temperature is $1.41^{\circ} \mathrm{C}$ higher than that of the residential houses in Wonosobo.

TABLE V

THERMAL COMFORT COMPARISON

\begin{tabular}{|c|c|c|c|c|c|c|c|}
\hline \multirow[b]{2}{*}{ No } & \multirow[b]{2}{*}{ Temperature } & \multicolumn{2}{|c|}{$\begin{array}{c}\text { Offices in } \\
\text { Jakarta }\end{array}$} & \multicolumn{2}{|c|}{$\begin{array}{l}\text { Schools in } \\
\text { Bandung }\end{array}$} & \multicolumn{2}{|c|}{$\begin{array}{l}\text { Houses in } \\
\text { Wonosobo }\end{array}$} \\
\hline & & 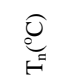 & $\underbrace{0}_{5}$ & 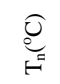 & $\underbrace{0}_{\substack{5 \\
H}}$ & $\underset{0}{0}$ & $\underbrace{0}_{\substack{5 \\
H^{0}}}$ \\
\hline 1 & $\begin{array}{c}\text { Air } \\
\text { Temperature } \\
\left(T_{a}\right)\end{array}$ & 27.2 & $\begin{array}{l}25.4- \\
29.0\end{array}$ & 24.7 & $\begin{array}{c}23.0 \\
- \\
26.5 \\
\end{array}$ & 24.47 & $\begin{array}{c}21.85 \\
- \\
27.11 \\
\end{array}$ \\
\hline 2 & $\begin{array}{c}\text { Globe } \\
\text { Temperature } \\
\left(\mathrm{T}_{\mathrm{g}}\right)\end{array}$ & - & - & 25.7 & $\begin{array}{c}22.2 \\
- \\
27.4 \\
\end{array}$ & 24.14 & $\begin{array}{c}21.63 \\
- \\
26.65 \\
\end{array}$ \\
\hline 3 & $\begin{array}{c}\text { Operative } \\
\text { Temperature } \\
\left(\mathrm{T}_{\mathrm{o}}\right)\end{array}$ & 27.2 & $\begin{array}{l}25.7- \\
28.8\end{array}$ & 25.4 & $\begin{array}{c}23.8 \\
- \\
27.0\end{array}$ & 24.17 & $\begin{array}{c}21.65 \\
- \\
26.68\end{array}$ \\
\hline 4 & $\begin{array}{c}\text { Equivalent } \\
\text { Temperature } \\
\left(\mathrm{T}_{\mathrm{ET}}\right)\end{array}$ & 26.4 & $\begin{array}{l}24.9- \\
27.9\end{array}$ & - & - & 25.08 & $\begin{array}{c}22.22 \\
- \\
27.93\end{array}$ \\
\hline 5 & $\begin{array}{c}\text { Standard } \\
\text { Effective } \\
\text { Temperature } \\
\left(\mathrm{T}_{\mathrm{SET}}\right)\end{array}$ & - & - & 26.1 & $\begin{array}{c}24.2 \\
-28\end{array}$ & 24.69 & $\begin{array}{c}22.07 \\
- \\
27.30\end{array}$ \\
\hline
\end{tabular}


This result is relevant to the thermal comfort finding in Wonosobo stating that cold regions have different thermal comforts than hot areas [21], [22]. The comfort zone in the residential houses is quite low, ranging from $27.93^{\circ} \mathrm{C}$ to $21.63^{\circ} \mathrm{C}$ which is different from that at the office or college buildings which are ranging from $22.2^{\circ} \mathrm{C}$ to $29.0^{\circ} \mathrm{C}$. Due to the low temperature, the respondents who participate in the research conducted at the residential houses in Wonosobo feel more comfortable than at the office or college buildings in Jakarta or Bandung.

The difference between the Humphreys' neutral temperature prediction $\left(21.9^{\circ} \mathrm{C}\right)$ and the result obtained from the field study on neutral temperature $\left(24.47^{\circ} \mathrm{C}\right)$ is $2.57^{\circ} \mathrm{C}$. Meanwhile, the difference between the result obtained from the field study on neutral temperature and that of the Auliciems' $\left(22.94^{\circ} \mathrm{C}\right)$ is $1.53^{\circ} \mathrm{C}$.

There is no significant difference between PMV prediction (0.057) and AMV value (-0.06), which is equal to only 0.117 . However, the results of PMV show that the average occupants of residential houses are predicted to feel neutral to slightly warm while those of AMV show that they feel indifferent to cold. These findings are following those of the previous studies assuming that PMV is less feasible to predict the naturally ventilated buildings [23][24].

\section{IV.CONCLUSION}

Comfort temperature for the traditional residential houses located in the mountainous tropical areas is $24.47^{\circ} \mathrm{C} \mathrm{T}_{\mathrm{a}}$ or $24.14^{\circ} \mathrm{C} \mathrm{T}_{\mathrm{g}}$ or $24.17^{\circ} \mathrm{C} \mathrm{T}_{\mathrm{o}}$ or $25.08^{\circ} \mathrm{C} \mathrm{T}_{\mathrm{ET}}$ or $24.69^{\circ} \mathrm{C} \mathrm{T}_{\mathrm{SET}}$. The comfort zone is ranging between $21.85^{\circ} \mathrm{C}-27.11^{\circ} \mathrm{C} \mathrm{T}_{\mathrm{a}}$ or $21.63^{\circ} \mathrm{C}-26.65^{\circ} \mathrm{C} \mathrm{T}$ or $21.65^{\circ} \mathrm{C}-26.68^{\circ} \mathrm{C} \mathrm{T}$ or $22.22^{\circ} \mathrm{C}$ $-27.93^{\circ} \mathrm{C} \mathrm{T}_{\mathrm{ET}}$ or $22.07^{\circ} \mathrm{C}-27.30^{\circ} \mathrm{C} \mathrm{T}_{\mathrm{SET}}$. All the obtained comfort temperatures are lower than those in Jakarta and Bandung.

Humphreys' comfort temperature prediction is $2.57^{\circ} \mathrm{C}$ lower than the neutral temperature obtained from the field study. Conversely, the Auliciems' comfort temperature prediction is $1.53^{\circ} \mathrm{C}$ higher than the neutral temperature obtained from the field study. It suggests the presence of adaptation to the local temperature. The result of respondents' thermal prediction using PMV shows a slight difference of only 0.117 points.

\section{ACKNOWLEDGEMENT}

The researchers would like to express their gratitude to the Indonesian Ministry of research and technology for providing funds for this research.

\section{REFERENCES}

[1] R. Kramer, L. Schellen, H. Schellen, and B. Kingma, "Improving rational thermal comfort prediction by using subpopulation characteristics: A case study at Hermitage Amsterdam," Temperature, vol. 4, no. 2, pp. 187-197, 2017

[2] S. Chowdhury, Y. Hamada, and K. Shabbir Ahmed, "Indoor heat stress and cooling energy comparison between green roof (GR) and non-green roof (n-GR) by simulations for labor intensive factories in the tropics," Int. J. Sustain. Built Environ., vol. 6, no. 2, pp. 449-462, 2017

[3] J. K. Maykot, R. F. Rupp, and E. Ghisi, "A field study about gender and thermal comfort temperatures in office buildings," Energy Build., vol. 178, pp. 254-264, 2018.
[4] G. M. Elrayies, "Thermal performance assessment of shipping container architecture in hot and humid climates," Int. J. Adv. Sci. Eng. Inf. Technol., vol. 7, no. 4, pp. 1114-1126, 2017.

[5] A. S. Hendriani, Hermawan, and B. Retyanto, "Comparison analysis of wooden house thermal comfort in tropical coast and mountainous by using wall surface temperature difference," AIP Conf. Proc., vol. 1887, 2017.

[6] H. Hermawan, H. Hadiyanto, S. Sunaryo, and A. Kholil, "Analysis of thermal performance of wood and exposed stone-walled buildings in mountainous areas with building envelop variations," J. Appl. Eng. Sci., vol. 17, no. 3, pp. 321-332, 2019.

[7] M. Indraganti and D. Boussaa, "Comfort temperature and occupant adaptive behavior in offices in Qatar during summer," Energy Build., vol. 150 , pp. 23-36, 2017.

[8] M. L. Costa, M. R. Freire, and A. Kiperstok, "Strategies for thermal comfort in university buildings - The case of the faculty of architecture at the Federal University of Bahia, Brazil," J. Environ. Manage., vol. 239, no. August 2018, pp. 114-123, 2019.

[9] R. Maiti, "PMV model is insufficient to capture subjective thermal response from Indians," Int. J. Ind. Ergon., vol. 44, no. 3, pp. 349361, 2014.

[10] S. Thapa, "Insights into the thermal comfort of different naturally ventilated buildings of Darjeeling, India - Effect of gender, age and BMI,” Energy Build., vol. 193, pp. 267-288, 2019.

[11] Y. Xiong, J. Liu, and J. Kim, "Understanding differences in thermal comfort between urban and rural residents in hot summer and cold winter climate," Build. Environ., vol. 165, no. September, p. 106393, 2019.

[12] M. C. Katafygiotou and D. K. Serghides, "Thermal comfort of a typical secondary school building in Cyprus," Sustain. Cities Soc., vol. 13, pp. 303-312, 2014.

[13] A. Albatayneh, D. Alterman, A. Page, and B. Moghtaderi, "The significance of the adaptive thermal comfort limits on the airconditioning loads in a temperate climate," Sustain., vol. 11, no. 2, 2019.

[14] Hermawan, E. Prianto, and E. Setyowati, "The analysis of thermal sensation vote on the comfort of occupants of vernacular houses in mountainous areas of Wonosobo, Indonesia," Int. J. Adv. Sci. Technol., vol. 130, pp. 33-48, 2019.

[15] W. Khalid, S. A. Zaki, H. B. Rijal, and F. Yakub, "Investigation of comfort temperature and thermal adaptation for patients and visitors in Malaysian hospitals," Energy Build., vol. 183, pp. 484-499, 2019.

[16] F. Khalvati and A. Omidvar, "Summer study on thermal performance of an exhausting airflow window in evaporatively-cooled buildings," Appl. Therm. Eng., vol. 153, no. January, pp. 147-158, 2019.

[17] H. Choi, Y. An, K. Kang, S. Yoon, and T. Kim, "Cooling energy performance and thermal characteristics of a naturally ventilated slim double-skin window," Appl. Therm. Eng., vol. 160, no. July, p. 114113, 2019.

[18] E. Prianto and P. Depecker, "Characteristic of airflow as the effect of balcony, opening design and internal division on indoor velocity: A case study of traditional dwelling in urban living quarter in tropical humid region," Energy Build., vol. 34, no. 4, pp. 401-409, 2002.

[19] E. Prianto and P. Depecker, "Optimization of architectural design elements in tropical humid region with thermal comfort approach," Energy Build., vol. 35, no. 3, pp. 273-280, 2003.

[20] T. H. Karyono, S. Heryanto, and I. Faridah, "Air conditioning and the neutral temperature of the Indonesian university students," Archit. Sci. Rev., vol. 58, no. 2, pp. 174-183, 2015.

[21] Hermawan, E. Prianto, E. Setyowati, and Sunaryo, "The comparison of vernacular residences' thermal comfort in coastal with that in mountainous regions of tropical areas," AIP Conf. Proc., vol. 1903, no. November 2017, 2017.

[22] Hermawan, Sunaryo, and A. Kholil, "A thermal performance comparison of residential envelopes at the tropical highland for occupants' thermal comfort," IOP Conf. Ser. Earth Environ. Sci., vol. 200, no. 1, pp. 0-7, 2018.

[23] S. Aghniaey, T. M. Lawrence, T. N. Sharpton, S. P. Douglass, T. Oliver, and M. Sutter, "Thermal comfort evaluation in campus classrooms during room temperature adjustment corresponding to demand response," Build. Environ., vol. 148, no. November 2018, pp. 488-497, 2019.

[24] L. A. López-Pérez, J. J. Flores-Prieto, and C. Ríos-Rojas, “Adaptive thermal comfort model for educational buildings in a hot-humid climate," Build. Environ., vol. 150, no. September 2018, pp. 181-194, 2019. 